\title{
Studies on an ulcerative stomatitis - obstructive rhinitis - pneumonia disease complex in hatchling and juvenile sea turtles Chelonia mydas and Caretta caretta
}

\author{
J. S. Glazebrook ${ }^{1, *}$, R. S. F. Campbell ${ }^{1}$, A. T. Thomas $^{2}$ \\ ${ }^{1}$ Graduate School of Tropical Veterinary Science \& Agriculture, James Cook University of North Queensland, Townsville, \\ Queensland 4810, Australia \\ ${ }^{2}$ Oonoonba Veterinary Laboratory, Queensland Department of Primary Industries, Townsville, Queensland 4810, Australia
}

\begin{abstract}
Three bacterial diseases (ulcerative stomatitis, obstructive rhinitis and pneumonia) and associated complexes were together responsible for mortality rates of up to $70 \%$ in farmed and oceanarium-reared turtles (Chelonia mydas and Caretta caretta). Hatchlings 5 to $12 \mathrm{wk}$ old and juveniles 3 to 6 mo old were particularly susceptible to ulcerative stomatitis and bronchopneumonia respectively (58.6 and $58.3 \%$ of the cases diagnosed). Obstructive rhinitis was secondary to ulcerative stomatitis, being present in $70 \%$ of hatchlings with mouth rot or 'canker' Focal pneumonia occurred more frequently in juveniles ( $81.8 \%$ or $9 / 11$ affected). The 5 disease complexes observed (ulcerative stomatitis - bronchopneumonia; ulcerative stomatitis - obstructive rhinitıs; ulcerative stomatitis - obstructuve rhinitis - bronchopneumonia; obstructive rhinitis - bronchopneumonia; and ulcerative stomatitis - focal pneumonia) were equally distributed amongst hatchlings and juveniles. It was not possible to compare the relative susceptibility of green turtles and loggerheads, because of the small number of loggerheads involved (3). The percentage of farmed and oceanarium-reared turtles showing one or more of these diseases was similar $[65 \%(65 / 100)$ and $66.6 \%(10 / 15)$ respectively]. The clinico-pathological features of the major diseases are described. Three bacteria (Vibrio alginolyticus, Aeromonas hydrophila and Flavobacterium sp.) were repeatedly isolated from cases of ulcerative stomatitis and obstructive rhinitis. In addition to the above organisms 4 genera of fungi (Paecilomyces sp., Penicillium sp., Aspergillus sp. and Fusarium sp.) were recovered from caseous material lodged inside the trachea and bronchi of turtles with bronchopneumonia. A therapeutic regime was tested on 42 hatchlings, 7 to $8 \mathrm{wk}$ old, using antibiotics and a topical disinfectant. The survival rate of individually-reared hatchlings $(71.5 \%)$ was significantly higher than the control group $(28.6 \%, \mathrm{p}<0.01)$ but not significantly higher than their group-reared counterparts $(57.2 \%, \mathrm{p}<0.05)$.
\end{abstract}

\section{INTRODUCTION}

Ulcerative stomatitis has been reported in many species of captive reptile throughout the world including the Greek tortoise Testudo graeca (Holt \& Cooper 1976) and European pond tortoise Emys orbicularis (Keymer 1978a) in England. The Greek tortoise showed a severe glossitis with disruption of the strati-

\footnotetext{
- Present address: Faculty of Aquatic Science \& Natural Resources Management, Deakin University, Warmambool, Victoria 3280, Australia
}

fied squamous epithelium lining the oral cavity. The plaque covering the tongue consisted of a blood clot, necrotic debris and inflammatory cells. The lesion was relatively superficial with slight damage to the lingual mucous glands but no apparent involvement of underlying muscle. From the available literature, ulcerative stomatitis appears to be primarily a disease of snakes rather than one of lizards or turtles.

There exists a number of opinions as to which organisms actually cause ulcerative stomatitis in reptiles. Aeromonas hydrophila has been isolated from oral lesions in the Greek tortoise (Holt \& Cooper 1976) and 
seems to play a major role in the pathogenesis of the disease.

In captive reptiles, obstructive rhinitis usually occurs in conjunction with ulcerative stomatitis and/or bronchopneumonia. Tortoises and turtles known to be susceptible include the Greek tortoise (Holt \& Cooper 1976), western box turtle (Jacobson 1978) and green turtle (Reme 1980). Jacobson (1978) reported that blockages in the nasal passages were often accompanied by respiratory distress, lethargy and anorexia. Obstruction was either partial or complete; unilateral or bilateral. The exudate was of mucoid (Holt \& Cooper 1976) or caseous (Jacobson 1978, Reme 1980) consistency. Gram-negative bacteria were isolated repeatedly from purulent material present in the upper respiratory tract of these animals. Aeromonas hydrophila was thought to be the main pathogen responsible (Holt \& Cooper 1976, Jacobson 1978), although Pseudomonas sp. and Proteus sp. may also be involved (Jacobson 1978).

Pneumonia has long been regarded as a potentially lethal disease in captive reptiles, and sea turtles have been shown to be susceptible. Zwart (1968) and Keymer (1978b) diagnosed the disease in green and loggerhead turtles from the Utrecht (The Netherlands) and London (England) zoos respectively. Jacobson et al. (1979) described an epidemic in mariculture-reared Chelonia mydas from Grand Cayman Island in the West Indies and Glazebrook (1981) reported a similar situation in farmed turtles from Australia. Glazebrook et al. (1981) also found that the lungs of a wild $C$. mydas caught near Townsville were seriously affected by eggs from flukes lodged in the heart. Jacobson et al. (1986) suggested a herpes virus was responsible for epizootics of lung, eye and trachea disease (LETD) in juvenile farmed C. mydas from Grand Cayman Island.

The clinical signs associated with the development of pneumonia in reptiles were variable. Aquatic species, e.g. sea turtles, showed a loss of equilibrium (Keymer 1978b, Jacobson et al. 1979, Glazebrook 1981 ) and the same general signs as snakes. Death in farmed and oceanarium-reared turtles was preceded by chronic wastage of the skeletal musculature (cachectic myopathy), as these turtles were unable to dive for food (Glazebrook 1981). Bronchopneumonia in farmed turtles was characterised by an accumulation of necrotic material, bacteria and mucus within the major bronchi and alveoli (Glazebrook 1981). Caseous material often blocked air passages completely, causing the collapse of affected alveoli and a degree of compensatory emphysema in adjacent air sacs.

Mariculture-reared Chelonia mydas from the West Indies also suffered from mycotic pneumonia (Jacobson et al. 1979). Their lungs showed multifocal granulomas with a central core containing branching, sep- tate hyphae. Caseous centres were surrounded by fibroblasts and giant cells. Granulomas often extended into airways and in several instances hyphae and spores had been liberated into these spaces. At the terminal airways there was an acute suppurative pneumonia with desquamation of the epithelium and the release of inflammatory cells into the lumen. In places the lungs were emphysematous, caused by thinning of the interstitial wall and the consequent dilation of the airways.

Helminth parasites have also been shown to seriously affect the lungs of sea turtles. Zwart (1968) found eggs in the lungs and other organs of a green turtle and worms were present in cross sections of the renal vein. Eggs were embedded in the lung parenchyma in the form of encapsulated granulomas. Giant cells were in the process of phagocytozing eggs and in some instances they had penetrated the egg membrane. Because of their specific location these parasites were considered to be filaria. Glazebrook et al. (1981) described microscopic changes caused by cardiovascular flukes Hapalotrema sp. and their eggs in a wild green turtle from north Queensland, Australia. The left lung showed extensive fibrosis and a mild diffuse infiltrate of inflammatory cells composed of lymphocytes, macrophages and a few plasma cells. Interstitial oedema was marked and epithelial cells lining the air passages were swollen. Egg granulomas were accompanied by focal haemorrhage in areas where erythrocytes and circulating eggs had escaped into the surrounding interstitium and eventually the alveoli. Macrophages were in close apposition to eggs free in the alveolar lumen. Parasitic granulomas were also a feature of the right lung where slight fibrosis had occurred. In oceanarium-reared turtles, this disease was treated with an injectable (IM) form of Droncit ${ }^{\circledR}$ (Bayer, Australia).

This paper describes a new disease complex in captive hatchlings and juveniles of Chelonia mydas and Caretta caretta, 3 to $52 \mathrm{wk}$ old, viz. ulcerative stomatitis - obstructive rhinitis - pneumonia, implicates certain marine bacteria/fungi as primary causative agents and suggests a method of treatment.

\section{MATERIALS AND METHODS}

Sources of material. Turtles suffering from ulcerative stomatitis, obstructive rhinitis and pneumonia were obtained from farms on Badu, Sue, Yam, Coconut and Yorke islands in the Torres Strait and from an oceanarium on Magnetic Island near Townsville, Australia (Glazebrook \& Campbell 1990a, b). From observations made during 10 visits to the turtle farms and from groups of turtles hatched at the Yorke Island Research Station and held until they were yearlings, 2 
age groups ( 5 to $12 \mathrm{wk}$ and 3 to $6 \mathrm{mo}$ ) were particularly susceptible to ulcerative stomatitis and bronchopneumonia respectively (see 'Results'). This led to a definite bias in the sampling.

Clinical examination. Each turtle was identified, weighed, measured and a note made of its age from farm records. Prior to euthanasia, the angle at which the turtle swam to the horizon was observed and the jaws were opened, to note the position and size of oral lesions.

Collection of lesion material. Bacteria and fungi: Suction from a sterile tuberculin syringe was used to remove caseous material from nasal passages and inoculate it directly onto culture media. A sterile cotton wool swab served to dislodge caseous material from early and advanced lesions in the oral cavity. Plugs of caseous material lodged in the trachea were sampled by means of a sterile tuberculin syringe and 21 gauge needle, directed down the air passage. Uncontaminated samples were obtained from the lungs by searing the surface with a red-hot scalpel blade and puncturing the area with a sterile Pasteur pipette.

Viruses: Portions of lung (away from necrotic areas) were wrapped in aluminium foil, placed in a glass ampoule and stored in liquid nitrogen. Tracheal scrapings were immersed in $2 \mathrm{ml}$ Eagles Basal Medium (BME) and frozen at $-20^{\circ} \mathrm{C}$. The turtles selected to test viral aetiology for bronchopneumonia were 6 to $8 \mathrm{mo}$ old and had been receiving intramuscular injections of vitamin A on Yorke Island. The microbial flora of the respiratory tract of clinically normal turtles was not examined.

Inoculation of media and identification of isolates. For viruses, green turtle kidney cells (GTKID) at passage level 16 were inoculated with emulsified lung tissue (Tissue Tek) or tracheal scrapings and incubated at $28^{\circ} \mathrm{C}$. Four times the normal concentration of antibiotics and fungizone was added to BME to suspend the cells. Three passages were carried out before a result was considered negative.

Both selective and non-selective media were used for the isolation of bacteria. Non-selective media included salt blood agar, Simidu and Hasuo medium (SH or seawater agar) and trypticase soy agar. Rimler Shotts medium was employed for the isolation of Aeromonas hydrophila. Slopes were inoculated by means of a loop in a zigzag pattern and incubated at ambient temperatures in the field and at $25^{\circ} \mathrm{C}$ in the laboratory for 2 to $3 \mathrm{~d}$. Corn meal was used for the isolation of fungi. Identifications were performed by Dr W. Shipton of James Cook University, Animal Research Institute, Brisbane and Commonwealth Mycological Institute, Kew, England. Biochemical and antibiotic sensitivity tests were performed as described in Glazebrook \& Campbell (1990a, b) and also at the Oonoonba Veterinary Laboratory.
Pathology. Tissue samples were taken from the oral cavity, pharynx, kidney, spleen, lungs and also saggital sections of the head. They were fixed in $10 \%$ NBF and routinely stained with H\&E. Special stains included Gram, PAS, silver-methenamine and Giemsa

Therapy. Forty-two affected hatchlings 7 to $8 \mathrm{wk}$ old were transported from Badu Island to Townsville where they were treated for ulcerative stomatitis according to the regime of Burton (1978). The exudate was gentiy debrided, the oral cavity flushed with hydrogen peroxide and streptomycin sulphate (Glaxo, Melbourne) applied topically each day. Vitamin $C$ (Troy Lab, Sydney) was also administered orally at the rate of $50 \mathrm{mg} \mathrm{d}^{-1}$ and chlortetracyline (Pfizer, Sydney) injected intramuscularly ( $3 \mathrm{mg} 100 \mathrm{~g}^{-1}$ ) every 2 to $3 \mathrm{~d}$. Prior to the instigation of therapy the hatchlings were divided into 3 groups of 14 ; an untreated (control) group and 2 test groups ( 1 and 2 ).

In the controls and Group 1 hatchlings were kept 14 to a basin whereas in Group 2 they were housed individually in $1 \mathrm{l}$ plastic containers. Turtles were not fed during $10 \mathrm{~d}$ of treatment and water was changed twice daily. Live weights were recorded at the start of the experiment and on its completion. On Day 10,2 turtles with persistent lesions (controls) were sacrificed and in addition, 2 turtles from each of the test groups in which the lesions had apparently healed. Detailed microbiological and pathological examinations were performed on these 6 turtles. As well as caseous material from the oral cavity, heart blood, liver and kidney pulp were cultured.

\section{RESULTS}

\section{Prevalence}

A total of 140 captive and wild turtles were examined (Glazebrook et al. 1990a, b). Table 1 shows the

Table 1 Chelonia mydas and Caretta caretta. Prevalence of ulcerative stomatitis, obstructive rhinitis, bronchopneumonia, focal pneumonia and associated complexes in captive sea turtles (104 farmed and 15 oceanarium-reared)

\begin{tabular}{|lrr|}
\hline Disease/disease complex & Total & Percent \\
\hline Ulcerative stomatitis & 29 & 24.3 \\
Obstructive rhinitis & 10 & 8.4 \\
Bronchopneumonia & 13 & 10.9 \\
Focal pneumonia & 11 & 9.2 \\
Ulcerative stomatitis - obstructive rhinitis & 4 & 3.4 \\
Ulcerative stomatitis - bronchopneumonia & 3 & 2.5 \\
Ulcerative stomatitis - focal pneumonia & 1 & 0.8 \\
Ulcerative stomatitis - obstructive & 3 & 2.5 \\
$\quad$ rhinitis - bronchopneumonia & 3 & 1.7 \\
Obstructive rhinitis - bronchopneumonia & 2 & \\
\hline
\end{tabular}


Table 2. Chelonia mydas and Caretta caretta. Ulcerative stomatitis, obstructive rhinitis, bronchopneumonia and focal pneumonia: number, species, age and origin of affected turtles

\begin{tabular}{|c|c|c|c|c|c|c|}
\hline \multirow[t]{2}{*}{ Disease } & \multirow[t]{2}{*}{ Species } & \multicolumn{3}{|c|}{ Age } & \multirow[t]{2}{*}{ Origin } & \multirow[t]{2}{*}{ No. } \\
\hline & & Hatchlings & Juveniles & Yearlings & & \\
\hline \multirow[t]{7}{*}{ Ulcerative stomatitis } & C. mydas & 5 & 4 & 1 & Yorke Island & 10 \\
\hline & & 4 & 1 & - & Sue Island & 5 \\
\hline & & 1 & - & - & Yam Island & 1 \\
\hline & & 3 & 4 & - & Badu Island & 7 \\
\hline & & 2 & 2 & - & Magnetic Island & 4 \\
\hline & C. caretta & 2 & - & - & Magnetic Island & 2 \\
\hline & & & & & Total: & 29 \\
\hline \multirow[t]{5}{*}{ Obstructive rhinitis } & C.mydas & 6 & - & - & Yorke Island & 6 \\
\hline & & 2 & - & - & Coconut Island & 2 \\
\hline & & - & 1 & - & Badu Island & 1 \\
\hline & & - & 1 & - & Magnetic Island & 1 \\
\hline & & & & & Total: & 10 \\
\hline \multirow[t]{5}{*}{ Bronchopneumonia } & C. mydas & 5 & 4 & - & Yorke Island & 9 \\
\hline & & - & 2 & - & Coconut Island & 2 \\
\hline & & - & - & 1 & Yam Island & 1 \\
\hline & & - & 1 & - & Magnetic Island & 1 \\
\hline & & & & & Total: & 13 \\
\hline \multirow[t]{4}{*}{ Focal pneumonia } & C.mydas & 6 & 2 & - & Yorke Island & 8 \\
\hline & & 1 & 1 & - & Sue Island & 2 \\
\hline & & - & - & 1 & Yam Island & 1 \\
\hline & & & & & Total: & 11 \\
\hline
\end{tabular}

prevalence of ulcerative stomatitis, obstructive rhinitis, bronchopneumonia, focal pneumonia and associated complexes in captive sea turtles over a 3 yr period. Both farmed and oceanarium-reared turtles were affected. Individual diseases occurred more frequently than complex forms of a disease. Ulcerative stomatitis appeared in hatchlings at $3 \mathrm{wk}$, the other conditions arising from caseous material becoming lodged in the upper and lower respiratory tracts

\section{Number, species, age and origin of affected turtles}

\section{Ulcerative stomatitis}

Twenty-nine cases of ulcerative stomatitis were examined during summer 1977, 1978 and 1979. They consisted of 23 green turtles from farms in the Torres Strait and 4 green and 2 loggerhead turtles from an oceanarium on Magnetic Island near Townsville (Table 2). The latter had come from rookeries on Bramble Cay and Mon Repos Beach near Bundaberg. The disease was primarily one of hatchlings and young juveniles, $79.3 \%(23 / 29)$ of cases occurring in turtles 5 to $12 \mathrm{wk}$ old. Among the different age groups, $58.6 \%$ (17/29) of turtles suffering from the disease were hatchlings, $37.9 \%(11 / 29)$ juveniles, and $3.4 \%(1 / 29)$ yearlings.
The number of cases examined on any one island was an indication of the number of visits made to the island when the disease was at or near its peak, i.e. in summer.

\section{Obstructive rhinitis}

Ten green turtles ( 7 hatchlings and 3 juveniles) showed partial or complete obstruction of the nasal passages. The hatchlings were 4 to $8 \mathrm{wk}$ old and the juveniles 3, 5 and 7 mo old. Six were from Yorke Island, 2 from Coconut Island and 1 each from Badu and Magnetic Islands (Table 2). This disease was usually accompanied by ulcerative stomatitis and/or bronchopneumonia.

\section{Bronchopneumonia}

Turtles suffering from bronchopneumonia were those with plugs of caseous material lodged in the trachea and/or primary bronchi. A total of 13 cases were recorded (Table 1). For the first time, the number of juveniles suffering from a disease (7) exceeded the number of hatchlings (5) and only 1 yearling showed characteristic lesions. Once again, most cases were 
from Yorke Island (9), followed by Badu (2), Yam (1) and Coconut (1) (Table 2). All were farmed green turtles.

\section{Focal pneumonia}

Eleven cases of focal pneumonia were diagnosed Most, i.e. $8 / 11$ or $72.7 \%$ accurred on Yorke Island, with the remainder on Sue Island (2) and Yam Island (1). Juveniles were far more likely to develop the disease $(9 / 11$ or $81.8 \%$ affected), than hatchlings or yearlings (1/11 or $9.1 \%)$. Again, the disease was restricted to farmed green turtles.

\section{Disease complexes (Table 3)}

Three turtles were found to be suffering from both ulcerative stomatitis and bronchopneumonia on Yorke, Sue and Badu Islands. They were the same age 6 to $8 \mathrm{mo}$ ) as juveniles with bronchopneumonia only, although in the former, oral lesions had persisted. Ulcerative stomatitis and obstructive rhinitis occurred concurrently in 4 hatchlings ( 3 greens and 1 loggerhead) from Yorke and Magnetic Islands. The loggerhead concerned was $6 \mathrm{wk}$ old. A further complication occurred in 3 turtles ( 1 hatchling and 2 juveniles) suffering from ulcerative stomatitis, obstructive rhinitis and bronchopneumonia concurrently. Both farmed and oceanarium-reared turtles (from Badu, Coconut and Magnetic Islands) were affected. These diseases severely reduced the animals' ability to breathe and feed normally. In another 2 turtles (hatchling and juvenile), oral lesions had disappeared, leaving only those characteristic of obstructive rhinitis and bronchopneu- monia. Both animals had come from Yorke Island. Focal pneumonia was recorded in association with ulcerative stomatitis on only 1 occasion; in a juvenile turtle from Yorke Island.

\section{Field observations}

During the summers of 1977,1978 and 1979 all 4 conditions were reported on farms that had been supplied with new hatchlings at the start of the nesting season. It was not possible to determine the relative importance of the different diseases, i.e. morbidity and mortality rate, because farmed turtles were not separated on the basis of their age, diet and disease status. Islanders had attempted to clear blocked nasal passages with a tuberculin syringe but this provided only temporary relief. The development of ulcerative stomatitis and obstructive rhinitis in oceanarium-reared turtles during the winters of 1979 and 1980 was unexpected, as was the susceptibility of loggerheads to these diseases. Captive and wild loggerheads have hitherto been free of these diseases. Hawksbill turtles kept on Yorke Island never developed the disease

\section{Clinical signs}

The appearance of a plug of yellow, caseous material in the external nares of hatchlings 5 to $7 \mathrm{wk}$ old was usually the first overt sign of the ulcerative stomatitis obstructive rhinitis - pneumonia disease complex. Blockages occurred just as often in the left nasal passage as the right (5.5), although in 1 turtle (Fig. 1) both nares were involved. Out of 10 cases, bilateral lesions were recorded on only 1 occasion.

Table 3. Chelonia mydas and Caretta caretta. Disease complexes: number, species, age and origin of affected turtles

\begin{tabular}{|c|c|c|c|c|}
\hline Disease complex & Species & Age & Origin & No. \\
\hline Ulcerative stomatitis - bronchopneumonia & C. mydas & Juveniles & $\begin{array}{l}\text { Yorke Island (1) } \\
\text { Sue Island (1) } \\
\text { Badu Island (1) }\end{array}$ & 3 \\
\hline $\begin{array}{l}\text { Ulcerative stomatitis - obstructive } \\
\text { rhinitis }\end{array}$ & $\begin{array}{l}\text { C. mydas, } \\
\text { C. caretta }\end{array}$ & Hatchlıngs & $\begin{array}{l}\text { Yorke Island ( } 3 \text { ) } \\
\text { Magnetic Island (1) }\end{array}$ & 4 \\
\hline $\begin{array}{l}\text { Ulcerative stomatitis - obstructive } \\
\text { rhinitis - bronchopneumonia }\end{array}$ & C. mydas & $\begin{array}{l}\text { Hatchlings, } \\
\text { juveniles }\end{array}$ & $\begin{array}{l}\text { Badu Island (1) } \\
\text { Coconut Island (1) } \\
\text { Magnetic Island (1) }\end{array}$ & 3 \\
\hline Obstructive rhinitis - bronchopneumonia & C. mydas & $\begin{array}{l}\text { Hatchling } \\
\text { and juvenile }\end{array}$ & Yorke Island & 2 \\
\hline Ulcerative stomatitis - focal pneumonia & C. mydas & Juvenile & Yorke Island & 1 \\
\hline
\end{tabular}




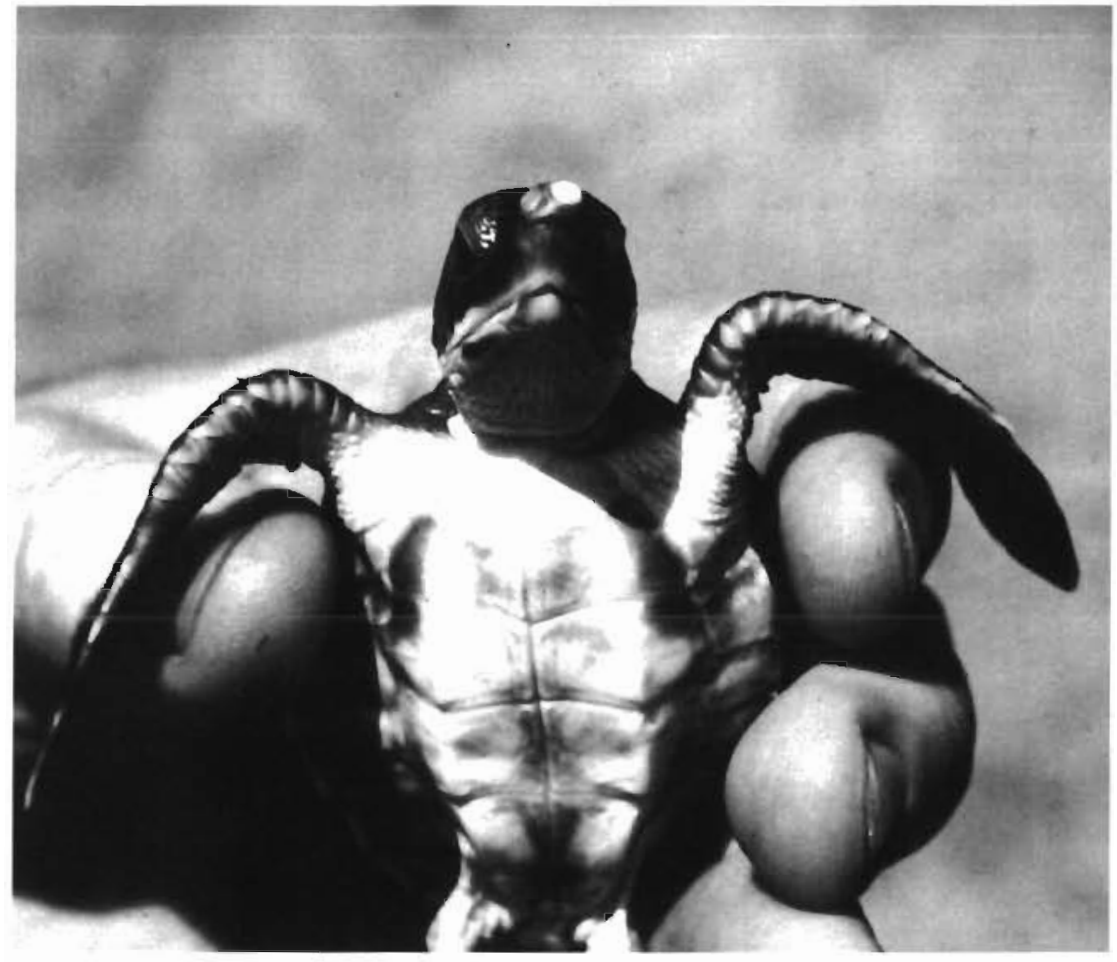

Fig. 1. Chelonia mydas. Obstructive rhinitis in a $6 \mathrm{wk}$ old hatchling. Note blockages in both nasal passages

On closer examination, the oral cavity contained an accumulation of yellow, caseo-purulent material adjacent to the glottis and on the lateral aspects of the tongue. The amount of exudate present depended on the age of the animal. so that in hatchlings it occupied most of the oral cavity. Lesions on the roof of the oral cavity were generally smaller and not associated with an intense proliferative response. In addition, the oral mucosa was noticeably inflamed in the immediate vicinity of the lesions. Grossly, the level of tissue oedema was difficult to estimate. Debridement of caseous material caused slight bleeding, indicating the presence of false membranes beneath necrotic areas. When hatchlings attempted to feed and breathe, superficial layers of caseous exudate were dislodged and became fixed in the nasal passages and trachea. Hatchlings in the advanced stages of the disease showed open mouth breathing and dyspnoea or 'air hunger'. Hatchlings and juveniles with broncho-and focal pneumonia showed a loss of equilibrium and laboured respiration. Severely affected animals floated motionless on the surface of the water, with occasional bursts of activity,

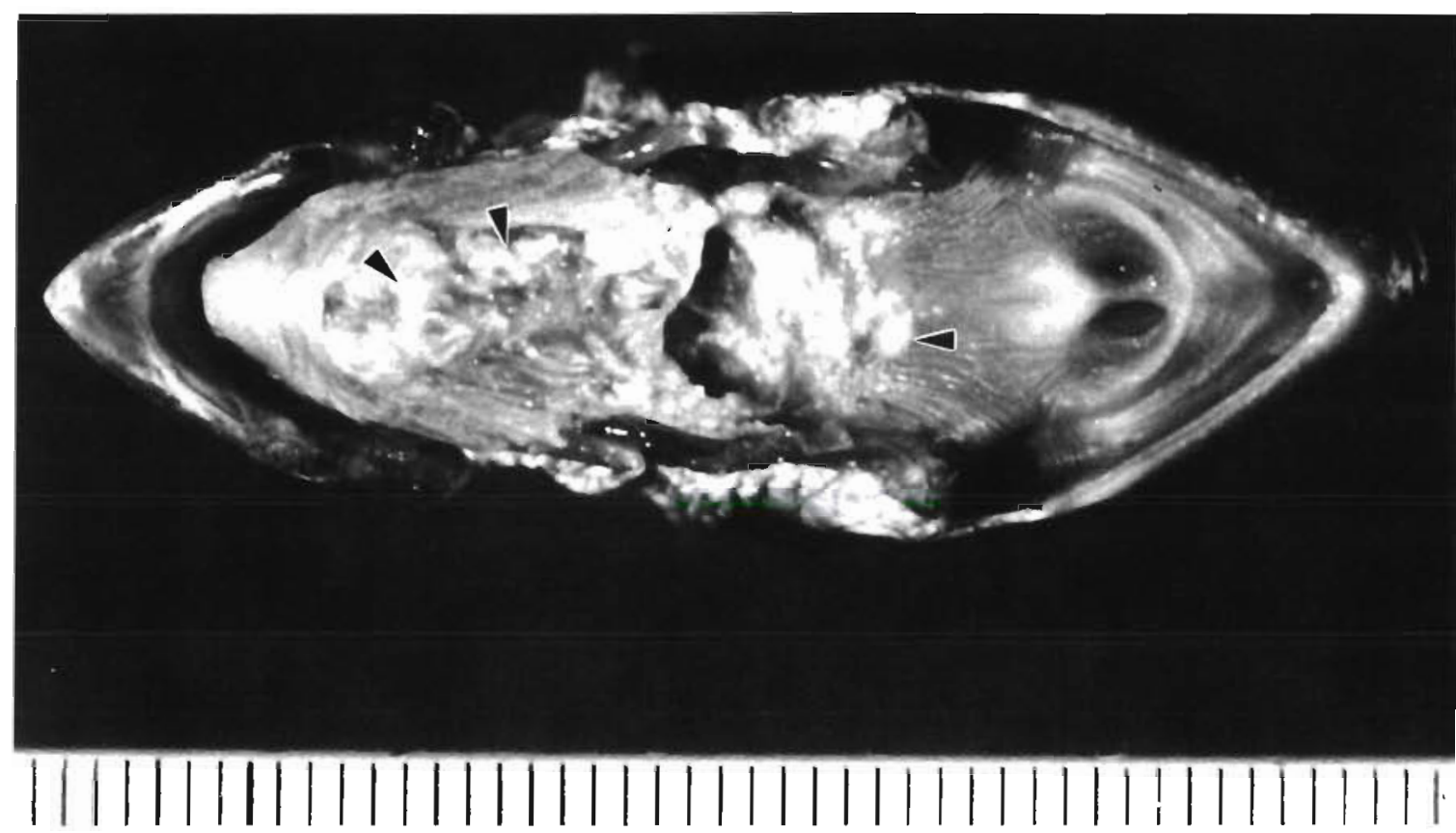

Fig. 2. Chelonia mydas. Ulcerative stomatitis in a $6 \mathrm{wk}$ old hatchling. Caseous lesions (arrows) can be seen on the dorsum of the tongue and palate. Ruler in $\mathrm{mm}$ 


\section{Gross and microscopic pathology}

\section{Ulcerative stomatitis}

The initial lesions of ulcerative stomatitis appeared on the side of the tongue or adjacent to the glottis and took the form of yellow plaques 1 to $2 \mathrm{~mm}$ in diameter surrounded by a zone of inflammation. In advanced cases these lesions were larger (2 to $4 \mathrm{~mm}$ diam.) (Fig 2), and consisted of a gross accumulation of caseous material which, when debrided, left a distinct depression in the oral mucosa. Many were subject to bleeding. In addition, lesions occurred on the roof of the pharynx and extended back towards the oesophagus. Of the 29 cases recorded (Table 1), 2 (6.9\%) were considered to be in the initial stages of the disease, i.e. lesions with very little caseous material, $21(72.4 \%)$ in the advanced stages and $6(20.7 \%)$ in the convalescent stages. The number of lesions present ranged from 1 or 2 (early and persistent cases) to 6 (advanced lesions). Pus dislodged during the processes of swallowing food or expelling water from the oral cavity frequently caused a muco-purulent rhinitis.

Saggital sections showed caseous material inside the oral cavity and a light to moderate lymphocytic infiltrate in the submucosa. As the epithelium degenerated it was replaced by an eosinophilic layer of necrotic material and basophilic clouds of bacteria. With sub- sequent ulceration, macrophages and eosinophils became additional features of the infiltrate and the endothelial cells of adjacent vessels were swollen. Lymphocytes could be seen passing through the walls of capillaries and into the submucosa which was oedematous. The epithelium bordering the ulcer was frequently hyperplastic.

Fig 3 shows an ulcer stained for fibrin with Martius scarlet blue. A diphtheritic plaque composed of serofibrinous material (scarlet) had formed over the eroded area and the cytoplasmic granules (orange-red) of the underlying eosinophils were prominent. There was also a number of secondary changes which had resulted from circulating bacteria releasing their toxins viz. degenerative tubular disease of the kidneys $(16 / 29)$, myocardial degeneration (7/29), reticuloendothelial hyperplasia in the spleen $(2 / 29)$ and dilation of the sinusoids in the liver (3/29). Toxic changes in the kidney were generalised. In severe cases the normal architecture of the tubular cells forming the collecting ducts had been destroyed leaving an amorphous, eosinophilic mass and causing a loss of patency. As well as myocardial degeneration, endothelial macrophages were swollen and in 1 turtle an intravascular clot had formed. Swollen hepatocytes in centro-lobular areas of the liver were a further indication of a septicaemic-toxaemic condition.

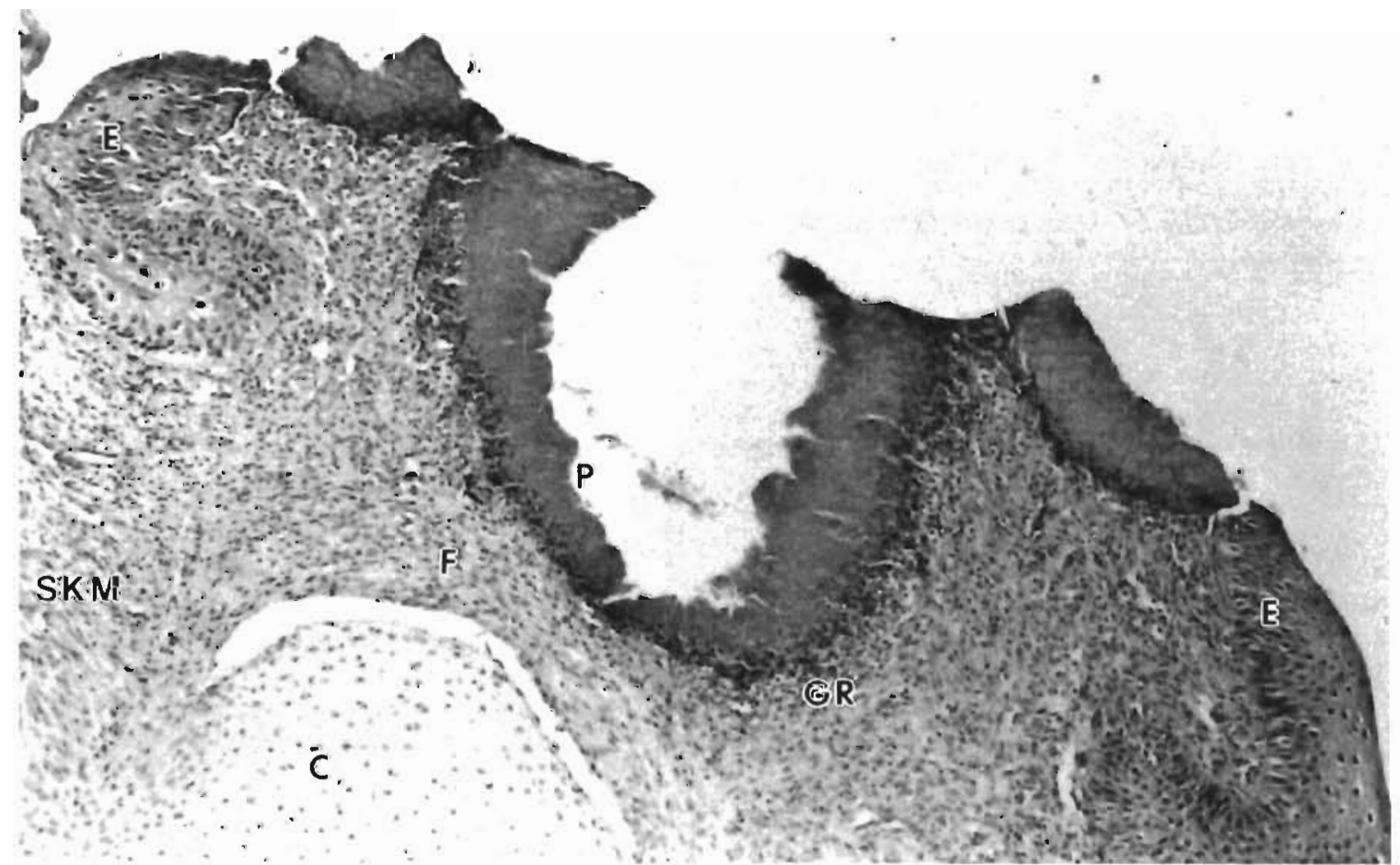

Fig. 3. Chelonia mydas. Ulcer on the tongue of a $7 \mathrm{wk}$ old hatchling. The plaque (P) consists of serofibrinous material, pyknotic nuclei and cellular debris. A layer of granulocytes (GR) lies immediately beneath the plaque and adjacent to fibrous tissue (F). One of the cartilaginous rings (C) which surround the glottis can be seen attached to skeletal muscle (SKM). Intact epithelium (E) borders the lesion. Martius scarlet blue (MSB). $63 \times$ 


\section{Obstructive rhinitis}

When stained with $H \& E$, necrotic material inside the nasal passages consisted of an amorphous, eosinophilic mass containing pyknotic nuclei and basophilic clouds of bacteria. In 1 turtle hyphae and a small number of erythrocytes were present. The exudate had a layered appearance and epithelial cells adjacent to the plug were swollen and vacuolated. A PAS stain showed a large amount of mucus in the lumen. There was surprisingly little cellular response, i.e. lymphocytic infiltrate in nasal tissues. In some sections there was a transition from squamous to columnar (glandular) epithelium. On the basis of these findings, a diagnosis of muco-purulent rhinitis was made. Of the 10 cases diagnosed (Table 1), 4 had degenerative tubular disease, 2 displayed toxic changes in the myocardium and 2 had immunologically reactive spleens.

\section{Bronchopneumonia}

Bronchopneumonia in captive sea turtles was characterised by the accumulation of necrotic material, bacteria and mucus in the bronchi and alveoli (Fig. 4) and an occasional granuloma in the interstitium. The condition could best be described as focal, interstitial bronchopneumonia.

Necrotic material in the trachea and major bronchi consisted of an amorphous eosinophilic substance plus numerous macrophages and clumps of bacteria. In the trachea, 3 distinct zones were apparent: a necrotic centre surrounded by macrophages and peripheral populations of lymphocytes and eosinophils. Giemsa staining revealed the presence of eosinophils in the lumen. In addition, large amounts of mucus had been released from the adjacent pseudo-stratified columnar epithelium which was itself swollen and vacuolated.

The alveolar exudate was similar to that observed in the upper respiratory tract. Caseous material often blocked air passages completely, causing the collapse of affected alveoli and a degree of compensatory emphysema in adjacent air sacs (Fig. 5). Vessels nearby were also congested. Degenerative changes in the alveolar wall ranged from hypertrophy to desquamation. These changes, combined with the interstitial infiltrate surrounding the alveolus (Figs. $6 \& 7$ ), permitted use of the term alveolitis to describe the overall pathology.

The lungs showed a generalised inflammatory response. Interstitial oedema was common and the infiltrate was comprised of lymphocytes, eosinophils, macrophages and some plasma cells.

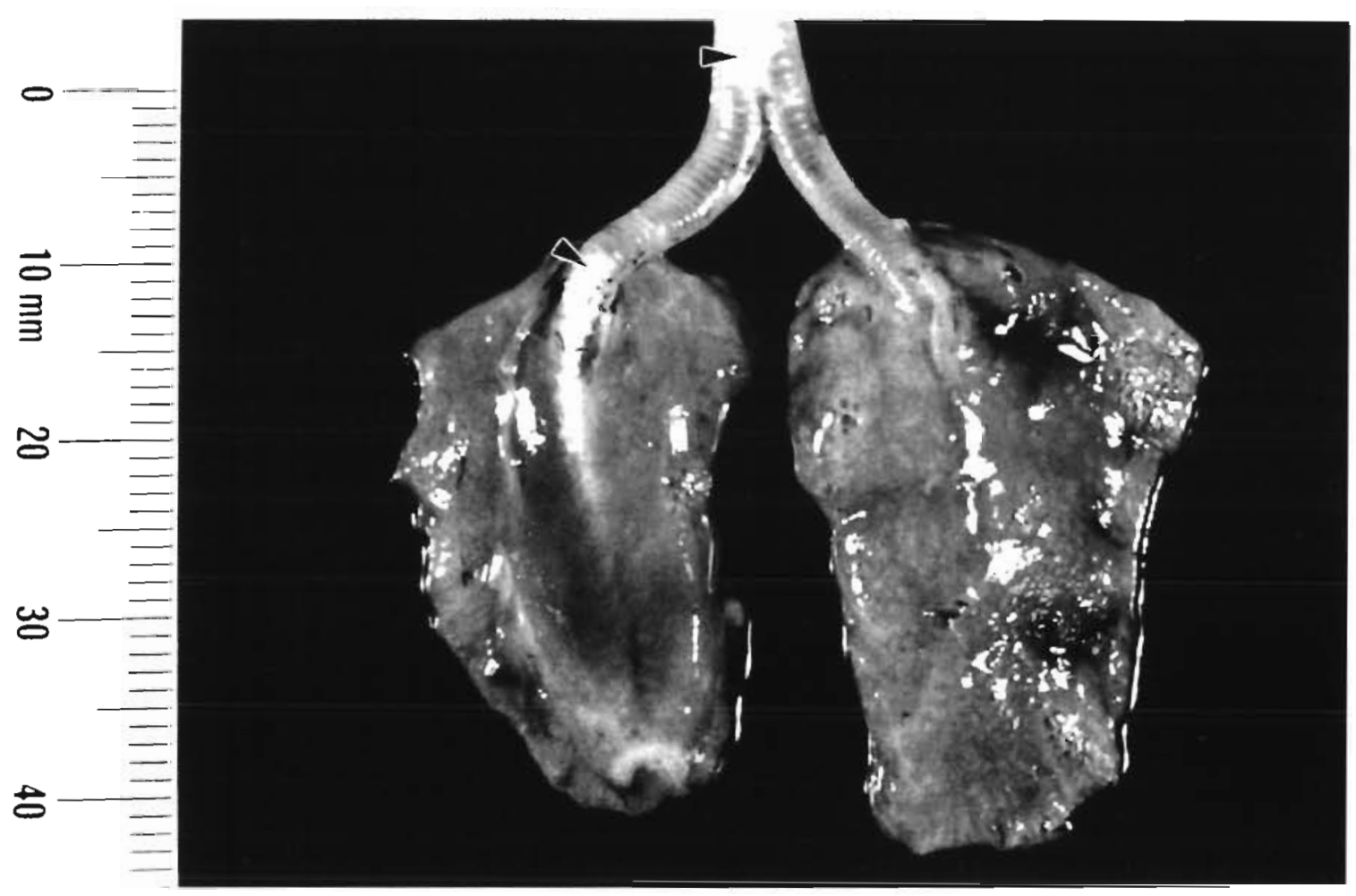

Fig. 4. Chelonia mydas. Ventral view of the lungs of a 7 mo old juvenile with bronchopneumonia. The right lung is consolidated and plugs of caseous material (arrow) have become lodged in the primary bronchus. The left lung is normally aerated 


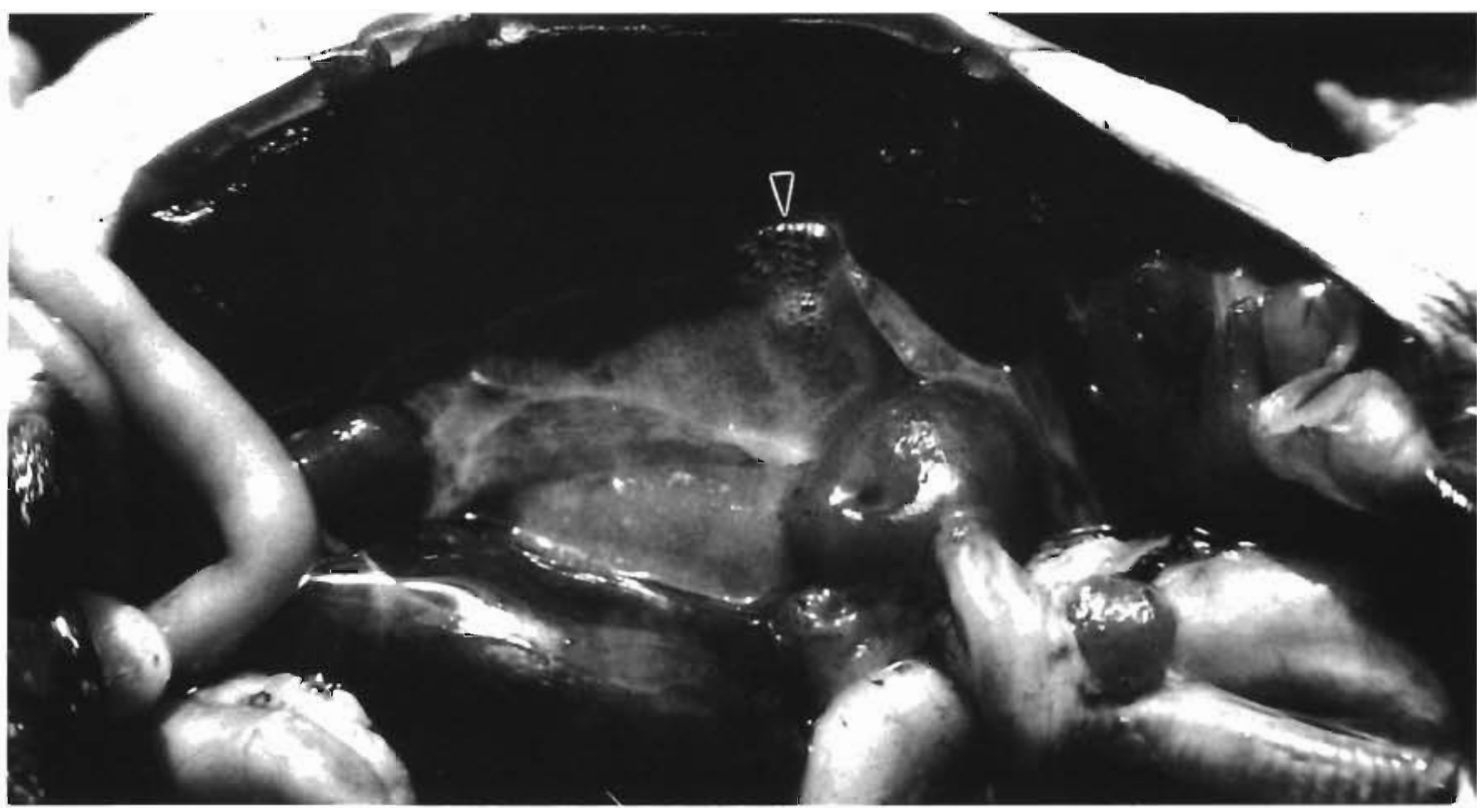

Fig. 5. Chelonia mydas. Compensatory emphysema (arrow) in the right lung of a 7 mo old juvenile

\section{Microbiology}

When examined microscopically, focal lung lesions consisted of multiple granulomas and a light to moderate lymphocytic infiltrate. In 3 out of 11 cases hyphae were seen surrounded by multinucleated giant cells (Fig 8). Air passages were not involved.
Attempts to isolate viruses from lung material were negative.

A mixed culture of aerobic bacteria was isolated from the lesions of ulcerative stomatitis, obstructive rhinitis, bronchopneumonia and focal pneumonia, and
Fig. 6. Chelonia mydas. Bronchopneumonia in a 7 mo old juvenile. The exudate consists of amorphous eosinophilic material containing pyknotic nuclei (PN) and alveolar macrophages (AM) associated with clumps of bacteria (B). The epithelium is undergoing hydropic degeneration (HD) and there is a moderate lymphocytic infiltrate (L) in the interstitium. Smooth muscle (SM) helps control the volume of the lung during diving. H\&E. $160 \times$

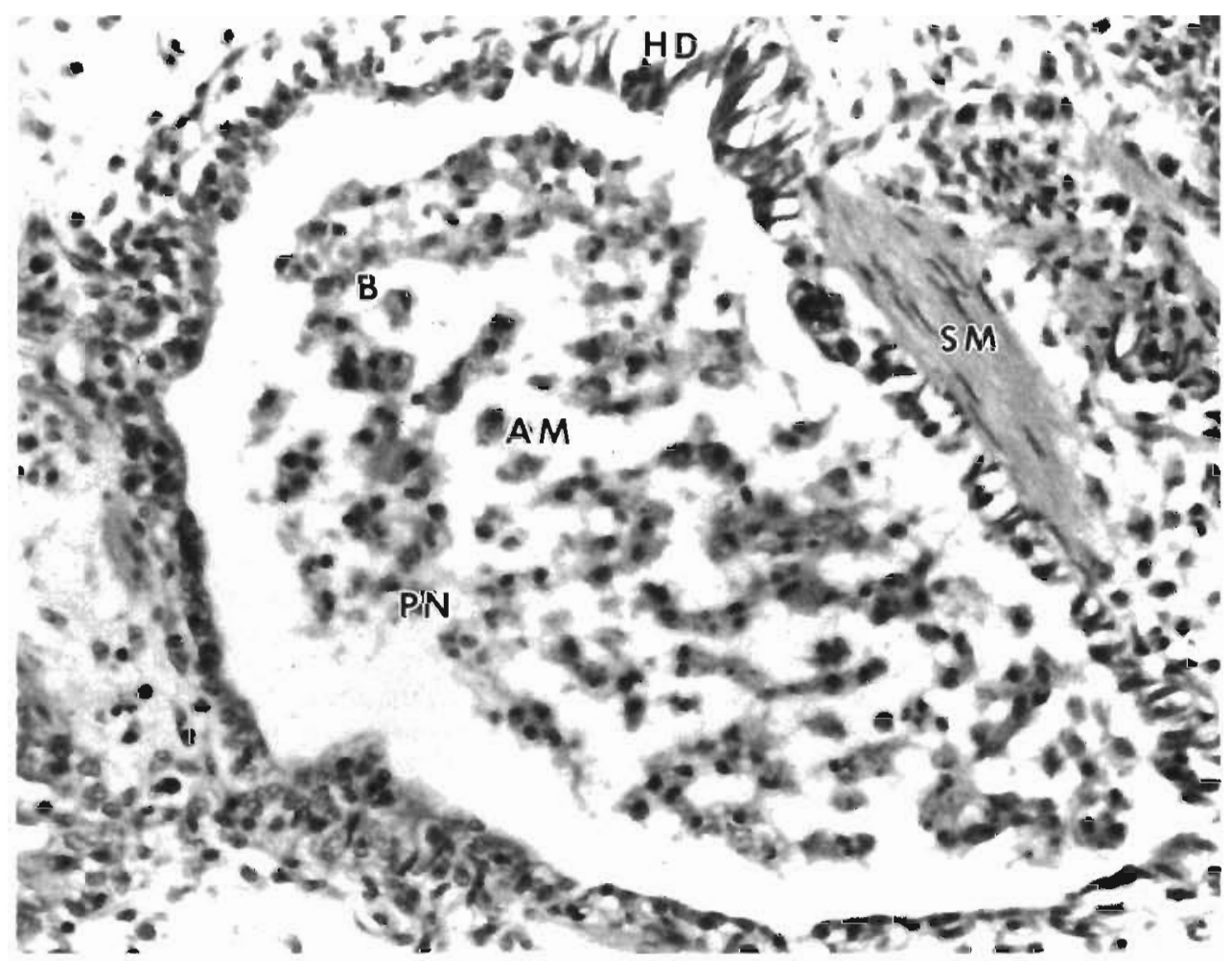




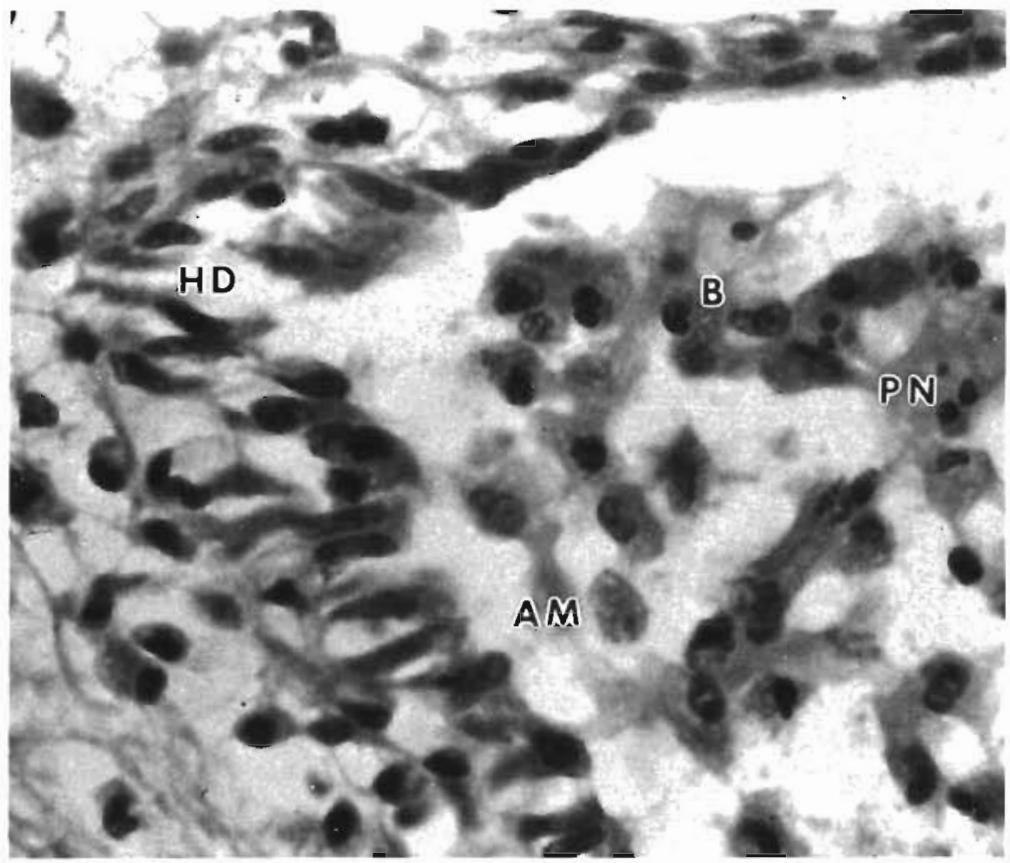

Fig. 7 Chelonia mydas. Bronchopneumonia in a 7 mo old juvenile. AM alveolar macrophages; $B$ : bacteria; $H D$ : hydropic degeneration of epithelium; PN: pyknotic nuclei. H\&E. $400 \times$

consisted of one or more pathogens plus a number of saprophytes (Table 4). All isolates were capable of growing on media containing $3.5 \%$ sodium chloride.

A wide range of bacteria was encountered in cases of 'mouth rot' or 'canker'. Three organisms known to be pathogenic for sea turtles (Glazebrook \& Campbell 1990a, b) viz Vibrio alginolyticus, Aeromonas hydrophila and Flavobacterium sp. and 2 saprophytes viz Micrococcus sp. and Proteus sp. were isolated from caseous material in the oral cavity of 2 turtles. However, judging by the number of times they were isolated (8/15), V. alginolyticus and A. hydrophila were mainly responsible for the disease. In addition, various saprophytes viz. Micrococcus sp., Acinetobacter calcoaceticus, Arthrobacter sp. and Proteus sp. were isolated. Only on 1 occasion was a fungus (Alternaria sp.) cultured from lesion material. $V$. alginolyticus, Aeromonas hydrophila and Flavobacterium sp. were cultured from heart blood on 3 separate occasions. $V$. alginolyticus and Flavobacterium sp. were also recovered from nasal exudate lobstructive rhinitis) as well as Pseudomonas aeruginosa and a non-oxidative pseudomonad.

Consistent with the above findings, Vibrio alginolyticus, Aeromonas hydrophila, Flavobacterium sp., Pseudomonas putrefaciens and a non-oxidative pseudomonad occurred in turtles with bronchopneumonia. Two members of the enterobacteriacae viz Arizona hinshairi and Escherichia coli were also present. However, this group differed mark-

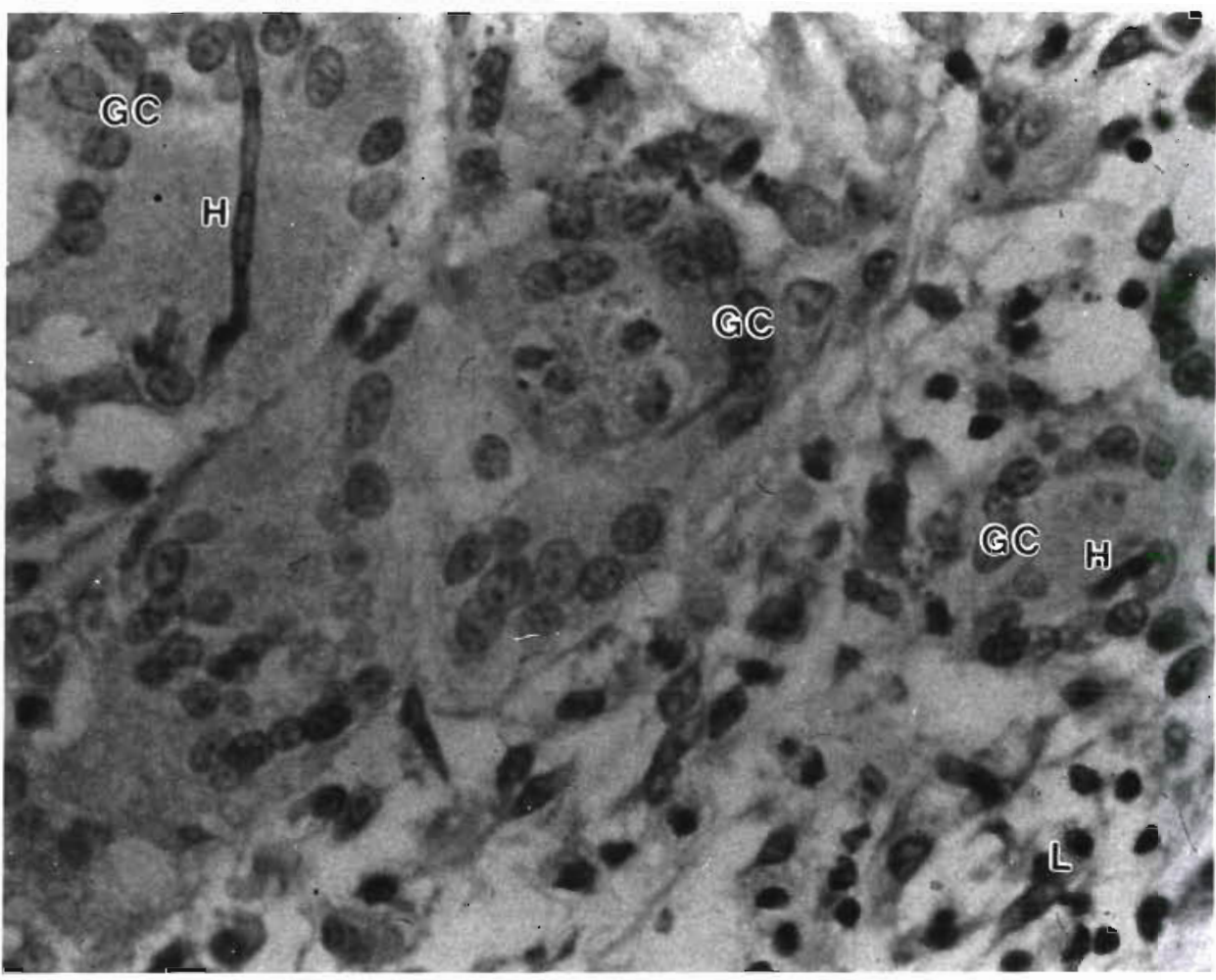

Fig. 8. Chelonia mydas. Mycotic pneumonia in a $3 \mathrm{mo}$ old juvonile. Fungal hyphae $(\mathrm{H})$ are surrounded by multinucleated giant cells (GC) and there is a moderate lymphocytic infiltrate (L) in the interstitium. H\&E. $400 \times$ 
Table 4. Bacteria, fungi and yeasts isolated from cases of ulcerative stomatitis, obstructive rhinitis, bronchopneumonia and focal pneumonia

\begin{tabular}{|c|c|c|c|c|}
\hline \multirow[t]{2}{*}{ Disease } & \multirow{2}{*}{$\begin{array}{l}\text { No. of } \\
\text { cases } \\
\text { examined }\end{array}$} & \multirow{2}{*}{$\begin{array}{c}\text { No. } \\
\text { cultured }\end{array}$} & \multicolumn{2}{|c|}{ Isolates (no. of times isolated) } \\
\hline & & & Bacteria & Fungi/yeasts \\
\hline Ulcerative stomatitis & 29 & 15 & $\begin{array}{l}\text { Vibrio alginolyticus (4), Aeromonas hydrophila (4), } \\
\text { A. liquefaciens (1), Flavobacterium sp. (5), } \\
\text { Pseudomonas aeruginosa (2), P. putrefaciens (1), } \\
\text { non-oxidative pseudomonads (2), } \\
\text { Klebsiella sp. (3). Micrococcus sp. (2), } \\
\text { Acinetobacter calcoaceticus (1), } \\
\text { Anthrobacter sp. (1), Proteus sp. (7), } \\
\text { Bacillus sp. (2) }\end{array}$ & Alternaria sp. (1) \\
\hline Obstructive rhinitis & 10 & 4 & $\begin{array}{l}V \text { alginolyticus (1), } P \text {. aeruginosa (1), } \\
\text { Flavobacterium sp. (1), } \\
\text { non-oxidative pseudomonad (1) }\end{array}$ & \\
\hline Bronchopneumonia & 13 & 11 & $\begin{array}{l}\text { V. alginolyticus (2), A. hydrophila (3), } \\
\text { Flavobacterium sp. (3), } \\
\text { P. putrefaciens (1), non-oxidative } \\
\text { pseudomonad (1), Arizona hinshairi (1), } \\
\mathrm{H}_{2} \mathrm{~S}+\mathrm{ve} \text { E. coli (1), Proteus sp. (2) }\end{array}$ & $\begin{array}{l}\text { Paecilomyces sp. (2), } \\
\text { Penicillium sp. (2), } \\
\text { Aspergillus sp. (1), } \\
\text { Fusarium scirpi (1), } \\
\text { Rhodotorula sp. (2) }\end{array}$ \\
\hline Focal pneumonia & 11 & 2 & $\begin{array}{l}\text { V. alginolyticus (2), } \\
\text { non-oxidative pseudomonad (1), } \\
\text { Micrococcus sp. (1), Proteus sp. (1) }\end{array}$ & \\
\hline
\end{tabular}

edly from the others in that caseous material from the trachea and major bronchi yielded 4 genera of fungi (Paecilomyces sp., Penicillium sp., Aspergillus sp. and Fusarium sp.) and a marine yeast (Rhodotorula sp.). $V$. alginolyticus and non-oxidative pseudomonads were also cultured from focal lung lesions together with Micrococcus sp. and Proteus sp. Fungi were conspicuous by their absence. Although acid fast bacilli (Mycobacterium sp.) were seen in granulomatous lesions from 2 turtles (Glazebrook \& Campbell 1990a), they were not considered to be a major cause of focal pneumonia.

The strains of Vibrio alginolyticus and Aeromonas hydrophila isolated (Table 4 ) had the same physical and biochemical properties as those from ulcerative skin lesions (Glazebrook \& Campbell 1990a). From the point of view of therapy, it was important to note that A. hydrophila was sensitive to chloramphenicol, streptomycin, neomycin and furoxone and resistant to chlortetracycline, oxytetracycline, penicillin, and sulphathiazole. Except for penicillin, $V$. alginolyticus was sensitive to all of the above antibiotics and also vibriostat $0 / 129$ and novobiocin. Flavobacterium spp. were slower growing than $V$. alginolyticus or $A$. hydrophila but nevertheless hydrolysed gelatin and possessed cytochrome oxidase. They were sensitive to chloramphenicol, chlortetracycline, oxytetracycline, penicillin and furoxone and resistant to neomycin and streptomycin. Non-oxidative pseudomonads (Table 4 ) were typically unreactive. On salt blood agar they appeared as low convex, grey colonies 2 to $3 \mathrm{~mm}$ in diameter (after $2 \mathrm{~d}$ at RT) with slight beta-haemolytic activity. Using the API 20E system only the cytochrome oxidase reaction was consistently positive. Pseudomonas aeruginosa and $P$. putrefaciens differed from non-oxidative pseudomonads in that they utilised glucose and mannitol and were decarboxylase positive. In addition, they had an 'earthy' smell and were strongly beta-haemolytic. Acinetobacter calcoaceticus was isolated from the oral cavity on only 1 occasion. After 2 to $3 \mathrm{~d}$ at room temperature, the colonies were grey in colour, 2 to $3 \mathrm{~mm}$ in diameter and slightly beta-haemolytic. Sugars were not utilised either oxidatively or fermentatively. The organism did, however, grow on Kosers citrate agar. Arizona hinshairi and an organism identified as $\mathrm{H}_{2} \mathrm{~S}$ positive Escherichia coli were recovered from the trachea of 2 turtles.

There was tremendous variation in the gross appearance of fungi isolated from the lungs (Table 4). On Sabourauds Dextrose agar, Penicillium sp. developed into a white or black, cottony growth which sporulated after 5 to $7 \mathrm{~d}$ at room temperature. Fusarium scirpi was slower growing ( $2 \mathrm{wk}$ to cover a $9 \mathrm{~cm}$ plate) and resembled 'sugar frosting'. It was pinkish-white in colour. Paecilomyces sp. was indistinguishable from Penicillium sp. on SDA. The marine yeast Rhodotorula sp. was pink with white spots and had a pasty consistency (on SDA). 
Table 5. Treatrnent of green turtle hatchlings suffering from ulcerative stomatitis (after Burton 1978)

\begin{tabular}{|llccc|}
\hline Group & Housing & \multicolumn{2}{c}{ Morbidity (\%) } & $\begin{array}{c}\text { Survival } \\
(\%) \\
\text { Control }\end{array}$ \\
& Basin & 100 & 0 & 71.4 \\
Group 1 & Basin & $(14 / 14)$ & $(0 / 4)$ & $(10 / 14)$ \\
& 100 & 12.5 & 42.8 \\
Group 2 & 1 1 plastic & $(14 / 14)$ & $(1 / 8)$ & $(6 / 14)$ \\
& buckets & $(14 / 14)$ & 40 & 28.6 \\
& & & $(4 / 10)$ & $(4 / 14)$ \\
\hline
\end{tabular}

\section{Therapy}

Table 5 shows the results of a therapy trial conducted on 42 hatchlings from Badu Island. In the control group, 4 hatchlings survived the $10 \mathrm{~d}$ experimental period without treatment and it appeared that their oral lesions had healed spontaneously. The survival rate of hatchlings in Group 2 (71.4\%) was significantly higher than the controls $(28.6 \%, \mathrm{p}<0.01)$, but not significantly higher than Group 1 (57.2\%, p<0.05). In Group 1 a definite improvement was noted in the overall condition of the 6 surviving turtles.

As the oral lesions regressed they became stronger and more active so that pacing activity against the side of the basin resumed. In Group 2, the practice of separating hatchlings during treatment allowed weaker individuals to survive.

In general, therapeutic measures were effective but needed to be applied for longer than $10 \mathrm{~d}$ as hatchlings lost weight and condition soon after the onset of the disease. Feeding could recommence with the successful healing of oral lesions. During the course of the experiment it was found that some lesions were difficult to debride, suggesting the presence of false membranes. Many turtles were, at the same time, suffering from traumatic ulcerative dermatitis and obstructive rhinitis. Healing was indicated grossly by a reduction in the amount of caseous material inside the oral cavity and microscopically by hyperplasia of the epithelium bordering the ulcers. This process was not always complete, especially in Group 2 where lesions still persisted in 4 out of the 10 survivors.

\section{DISCUSSION}

Jacobson et al. (1986) previously attributed conjunctivitis, tracheitis and pneumonia in farmed sea turtles 12 to 24 mo old to a herpes virus infection. Reme (1980) believed that a protozoan was responsible for a condition similar to stomatitis in 1 mo old hatchlings on
Reunion Island. In the present investigation the prevalence of the disease in farmed and oceanarium-reared turtles was $21.1 \%(23 / 104)$ and $40 \%(6 / 15)$ respectively. Hatchlings were particularly susceptible. During January and February 1979 the incidence of the disease in hatchlings in Yorke Island approached $100 \%$. The mortality rate over the same period was almost $50 \%$ (Yorke Island Research Station records), although traumatic ulcerative dermatitis also contributed to this figure.

The epizootiological picture observed on most islands was that of a disease which began in a small number of individuals, increased to a peak at 5 to $6 \mathrm{wk}$ and by $12 \mathrm{wk}$ had virtually disappeared. This picture differed from the isolated cases reported by Keymer (1978a) in tortoises. It was noteworthy that although ulcerative stomatitis was seen frequently in farmed and oceanarium-reared turtles, it did not occur in turtles reared in the laboratory specifically with the intention of identifying factors which contributed to multiple skin lesions in these animals. It appeared that the Torres Strait farms and Magnetic Island oceanarium had certain agents and/or factors in common which predisposed turtles to the disease. Based on observations made over a period of five year green turtles seemed to be more susceptible than loggerheads even though fewer of this species were kept (Table 2).

In contrast to tortoises (Holt \& Cooper 1976), oedema was not marked and haemorrhagic ulcers were the exception rather than the rule in green turtles. However, the accumulation of caseous material inside the oral cavity and a chronic loss of weight were two features common to turtles and tortoises with ulcerative stomatitis. Mouth ulcers in green turtles were termed subacute because of the caseo-purulent material present and the zone of inflammation (mainly mononuclear celis) which surrounded them.

The clinical examination of 29 cases of ulcerative stomatitis in green and loggerhead turtles allowed a clear picture to be obtained of changes that occurred at the microscopic level. As in the Greek tortoises of Holt \& Cooper (1976), oral lesions in green turtles, although ulcerative, were superficial with no involvement of underlying mucous glands or skeletal muscle. Oedema of the submucosa was not marked, but it was nevertheless a consistent change. The serofibrinous exudate which filled these spaces had come from adjacent vessels, there was no haemorrhage.

A feature common to all reptiles suffering from ulcerative stomatitis was focal degeneration of the epithelium lining the oral cavity into a layer of caseopurulent material containing pyknotic nuclei and numerous bacteria. Pus was always caseous in consistency because reptilian heterophils do not produce the lysozymes which are characteristic of polymorpho- 
nuclear leucocytes in mammals (Roberts 1989). Hyperplastic changes in the epithelium bordering the lesion represented an attempt by the host to repair the damaged area. The heavy mononuclear infiltrate in the submucosa (lymphocytes and macrophages) was a typical response to the invasion of bacteria. Eosinophils became numerous as the ulcers increased in size. Oedema of the submucosa was not marked in green turtles.

Two organisms, Vibrio alginolyticus and Aeromonas hydrophila, were frequently isolated from oral lesions in green turtles. A. hydrophila has been recovered from similar lesions in other reptiles on many occasions, although it was not always identified to species level (Burtscher 1931, Page 1966. Heywood 1968, Hess \& Rudy 1974, Holt \& Cooper 1976). V. alginolyticus, Flavobacterium sp. and non-oxidative pseudomonads have not been previously reported from reptiles with ulcerative stomatitis but may have contributed to the overall pathogenesis of the disease in green turtles, as well as constituting part of the normal oral flora. Aeromonas liquefaciens and Pseudomonas putrefaciens may have also played a part. Another organism isolated from green turtles, Pseudomonas aeruginosa, has been cultured from an Ecuadorian King Snake (Page 1961) and a Greek tortoise (Keymer 1978a). Klebsiella spp. have been implicated in snakes (Hess \& Rudy 1974) and tortoises (Holt et al. 1979) suffering from the disease. Micrococcus sp., A. calcoaceticus, Arthrobacter sp., Proteus sp. and Bacillus sp. were more likely to be commensals than opportunistic pathogens. The isolation of $V$. alginolyticus, A. hydrophila and Flavobacterium sp. from heart blood supported the hypothesis that most turtles died from septicaemia-toxaemia. The strain of Alternaria sp. isolated may have been a skin contaminant.

Obstructive rhinitis appears to be a new disease entity in sea turtles. Holt \& Cooper (1976) noticed a bloody discharge from the external nares of a Greek tortoise which they examined. More recently, Jacobson et al. (1991) succeeded in isolating Mycoplasma sp. and Pasteurella testudinus from the lungs of desert tortoises Xerobates agassizii with upper respiratory tract disease. The disease in green turtles was the direct result of necrotic material becoming lodged in the nasal passages. Of the 10 cases diagnosed, 7 were in hatchlings, no doubt due to the small diameter of their nasal passages. The hyoid apparatus was unable to generate sufficient pressure to clear the obstruction and the farmers' efforts provided only temporary relief. In 9 cases obstructive rhinitis occurred in conjunction with ulcerative stomatitis and/or bronchopneumonia and in each case the nasal exudate was the same consistency as that of the oral cavity and trachea. Microscopically, obstructive rhinitis differed from ulcerative stomatitis in that the epithelial lining of the oral cavity had been maintained and accordingly the local inflammatory response was minimal. Hypertrophic changes were likely to be related to an increased secretion of mucus. Fibrosis was not observed. The 4 organisms isolated from the nasal passages (Vibrio alginolyticus, Pseudomonas aeruginosa, Flavobacterium sp. and a non-oxidative pseudomonad) were also recovered from the oral cavity, although not always from the same animal. This suggested that they may have originated from that site. $V$. alginolyticus has been found to be pathogenic to green turtle hatchlings (Glazebrook $\&$ Campbell unpubl.). Fungal hyphae were seen in sections from 1 turtle but were not cultured.

Bronchopneumonia in farmed turtles resulted from the inspiration of necrotic material present in the oral cavity of hatchlings and juveniles with 'mouth rot' or 'canker'. This conclusion was supported by gross and microscopic findings and also cultural results. Attempts to culture a viral agent were consistently negative (after Jacobson et al. 1991). With 1 exception, affected turtles were aged between 1 and $8 \mathrm{mo}$. The Aldabra and Galapogos tortoises examined by Georg et al. (1962), Bengal monitor by Jacobson (1978) and Greek tortoises by Holt et al. (1979) were presumably adults. As well as the nasal discharge and associated respiratory difficulties seen by the last 2 authors, farmed turtles in the Torres Strait were listless and weak and showed a loss of equilibrium. At autopsy, there were areas of consolidation adjacent to major bronchi, particularly in the apical portion of the lung. The pus was of caseous consistency, whereas Jacobson (1978) and Holt et al. (1979) found 'fibropurulent material' and 'sero-sanguinous fluid' in the air passages of mariculture-reared green turtles and Greek tortoises respectively. The microscopic picture in farmed turtles suggested a bacterial infection although fungal hyphae were sometimes present, and no viral isolates were obtained from turtles with this disease. The exudate contained numerous bacteria many of which had been ingested by alveolar macrophages. Paecilomyces $\mathrm{sp}$. was cultured from the trachea and major bronchi and also elicited a granulomatous response in the interstitium. This organism has been isolated from similar cases in the Aldabra tortoise (Georg et al. 1962) and green turtle (Jacobson et al. 1979). Further, Aeromonas hydrophila has been recovered from tree pythons and mambas with bronchopneumonia and Proteus sp. from a tree boa (Jacobson 1978). Boa constrictors have been shown to be susceptible to Arizona $\mathrm{sp}$. in captivity (Boever \& Williams 1975), and the same may be true of green turtles. Vibrio alginolyticus and Flavobacterium sp. would have come from marine sources. Fungi have twice been implicated as a cause of focal pneumonia in captive sea turtles 
(Austwick 1974, Jacobson et al. 1979). Only low grade infections were diagnosed in Torres Strait farmed turtles. This was in sharp contrast to the situation in the West Indies where numerous hyphae were present in air passages as well as the interstitium (Jacobson et al. 1979).

Four authors [Page (1961), Heywood (1968), Jacobson (1978) and Holt et al. (1979)] suggested a connection between ulcerative stomatitis and bronchopneumonia in captive reptiles (snakes and tortoises). In green turtles obstructive rhinitis, bronchopneumonia and focal pneumonia were complications of the original condition viz ulcerative stomatitis, as complexes occurred only when accompanied by oral lesions. Farmed and oceanarium-reared turtles could suffer from multiple, unrelated diseases, e.g. traumatic ulcerative dermatitis and anisakiasis. This situation occurred in all age groups.

Rimler Shotts (RS) medium was useful for the isolation of Aeromonas hydrophila, an organism which also occurred on the skin of farmed turtles. However, some strains were sensitive to neomycin, an antibiotic which had been incorporated into the medium. Non-selective media (TSA, SH and CMA) showed the range of organisms present in the oral cavity and upper and lower respiratory tracts (Table 4). The API System 20E, proved unsuitable for the identification of marine bacteria, it being necessary to prepare specialised media e.g. Thornley's arginine and to modify Hugh and Leifson's oxidation/fermentation test. Martius scarlet blue (MSB) was ideal for the staining of mature fibrin which was scarlet in colour.

Regarding the treatment of hatchlings with ulcerative stomatitis (Table 5), the absence of food during the experimental period corresponded to the time when a severely affected animal would not feed. The live weight of turtles at the start of the experiment was an indication of how well they were coping with the disease. Indeed, 3 of the 4 controls which survived the $10 \mathrm{~d}$ experimental period were originally 'top weights'. On the other hand, turtles in Group 2 had approximately the same average weight as the controls prior to the instigation of therapy. Interpretation was made more difficult by the fact that many turtles were also suffering from obstructive rhinitis and traumatic ulcerative dermatitis. From the results obtained (Table 5), the best way to treat ulcerative stomatitis in green turtles was to individually isolate affected animals and administer the appropriate antibiotics (streptomycin topically, and chlortetracycline IM with a vitamin $C$ supplement for at least $2 \mathrm{wk}$ ).

Acknowledgements. The authors wish to thank farmers on Badu, Sue and Yorke islands for their cooperation and $\mathrm{Mr}$ P. Watson of 'Marine Gardens' on Magnetic Island for first alert- ing us to the occurrence of ulcerative stomatitis in loggerhead hatchlings.

\section{LITERATURE CITED}

Austwick, P. K. C. (1974). Report Nuffield Institute of Comparative Medicine. J. Zool., Lond. 173: 125-126

Boever, W. J., Williams, J. (1975). Arizona septicaemia in three boa constrictors. Vet. Med. small Anim. Clin. 30: $653-680$

Burton, J. (1978). Management and diseases of reptiles in captivity. Proc. No. 36. Course for veterinarians. Fauna Part B. Postgrad. Comm. in Vet. Sci., Univ. of Sidney, p. $247-270$

Georg, L. K., Williamson, W. M., Tilden, E. B., Getty, R. E. (1962). Mycotic pulmonary disease of captive giant tortoises due to Beauvaria bassiana and Paecilomyces fumoso-roseus. Sabouraudia 2: 80-86

Glazebrook, J. S. (1981). Diseases of farmed sea turtles. Proc. Melbourne Herpetol. Symp. Royal Melbourne Zoological Gardens, Australia, 19-21 May 1980. No. 22. Dominion Press, Victoria, p. 111-119

Glazebrook, J. S., Campbell, R. S. F. (1990a). A survey of the diseases of marine turtles in Northern Australia I. Farmed turtles. Dis. aquat. Org. 9: 83-95

Glazebrook, J. S., Campbell, R. S. F. (1990b). A survey of the disease of marine turtles in Northern Australia II. Oceanarium-reared and wild turtles. Dis. aquat. Org. 9: 97-104

Glazebrook, J. S., Campbell, R. S. F., Blair, D. (1981) Pathological changes associated with cardiovascular trematodes (Digenea: Spirorchiidae) in a green sea turtle Chelonia mydas (L). J. comp. Pathol 91: 361-368

Hess, J. L., Rudy, R. L. (1974). Ulcerative stomatitis in the python. Vet. Med. small Anim. Clin. Nov.: 1379-1381

Heywood, R. (1968). Aeromonas infection in snakes. Cornell Vet. 58: 236-241

Holt, P. E., Cooper, J. E. (1976). Stomatitis in the Greek tortoise Testudo graeca. Vet. Rec. 98: 156

Holt, P. E., Cooper, J. E., Needham, J. R. (1979). Diseases of tortoises: a review of seventy cases. J. small Anim. Pract. 20: $269-286$

Jacobson, E (1978). Diseases of the respiratory system in reptiles. Vet. Med. small Anim. Clin. 73(9): 1169-1175

Jacobson, E. R., Gaskin, J. M., Brown, M. B., Harris, R. K., Gardiner, C. H., LaPointe, J. L., Adams, H. P., Reggiardo, C. (1991). Chronic upper respiratory tract disease of freeranging desert tortoises (Xerobates agassizil). J Wildl. Dis. $27(2): 6-316$

Jacobson, E. R., Gaskin, J. M., Roelke, M., Greiner, E. C., Allen, J. (1986). Conjunctivitis, tracheitis and pneumonia associated with herpes virus infection in green sea turtles. J. am. vet. med. Ass. 9(1): 1020-1023

Jacobson, E. R., Gaskin, J. M., Shields, R. P., White, F. H. (1979). Mycotic pneumonia in mariculture-reared green sea turtles. J. Am. vet. med. Ass. 175: 929-932

Keymer, I. F. (1978a). Diseases of chelonians: (1). Necropsy survey of tortoises. Vet. Rec. 103: 548-552

Keymer, I. F. (1978b). Diseases of chelonians: (2). Necropsy survey of terrapins and turtles. Vet. Rec. 103: 577-582

Page, L. A. (1961). Experimental ulcerative stomatitis in King snakes. Cornell. Vet. 51:258-266

Page, L. A. (1966). Diseases and infections of snakes: a review. Bull. Wildl. Dis. Ass. 2: 111-125

Reme, A. (1980). Quelques problèmes sanitaires et pathologiques dans l'elevage intensif de la tortue marine 
(Chelonia mydas L.) à la Réunion. Rev. Elev. Med. Vet. Pays trop. 33(2): 177-192

Roberts, R. J. (1989). Fish pathology. Bailliere Tindall, London von Burtscher, J. (1931). Über die Mundfäule der Schlangen

Zool. Gart. (Leipzig) 4: 235-244

Responsible Subject Editor: P. Zwart, Utrecht, The Netherlands
Zwart, P. (1968). Parasitäre und mykotische Lungenaffektionen bei Reptilien. Verhandlungsbericht des X. Internationalen Symposiums über die Erkrankungen der Zootiere. Akademie Verlag, Berlin, p. $45-48$

Manuscript first received: July 14, 1991

Revised version accepted: March 9, 1993 